\title{
Prolactin release induced by suckling in lactating rats after L-DOPA treatment
}

\author{
R. P. Deis and J. Prilusky \\ Instituto de Investigacion Médica, Mercedes y Martin Ferreyra, Casilla de Correo 389, \\ Cordoba, Argentina
}

In a previous paper (Prilusky \& Deis, 1975) a blocking effect of L-DOPA on milk ejection and on prolactin release was demonstrated in lactating rats. The inhibitory effect of brain catecholamines on prolactin release is well established and it is probably mediated through dopamine (MacLeod, 1969; Donoso, Bishop, Fawcett, Krulich \& McCann, 1971). Since a catecholaminergic system in the central nervous system may regulate prolactin release in lactating rats, we investigated the effect of the suckling stimulus on prolactin release in rats treated with L-DOPA.

White primiparous lactating rats weighing about $270 \mathrm{~g}$ were used. Each litter was reduced to six young 4 days after birth. On the 10th day of lactation, the litter was separated from the mother in the early morning for $9 \mathrm{hr}$. The young were returned at 15.00 hours and allowed to suck for $30 \mathrm{~min}$. The young were weighed to the nearest $0 \cdot 1 \mathrm{~g}$ immediately before and after the suckling period to determine the amount of milk ejected by the mother. The procedure was repeated on 2 consecutive days and on the 3rd day blood samples were obtained, one from each rat, by heart puncture without anaesthesia at various times after the end of the suckling period. This simple method takes only a few seconds and does not disturb the rats (Vermouth \& Deis, 1974).

Rats in Group 1 were injected i.p. with L,3-4-dihydroxyphenylalanine (L-DOPA: Regis Chemicals; $10 \mathrm{mg} / 100 \mathrm{~g}$ body wt) suspended in physiological saline $30 \mathrm{~min}$ before the suckling period. The serum prolactin levels at $0,30,60,90,120,150,180$ and 210 min after the suckling period were measured by radioimmunoassay with two dose levels of serum (Niswender, Chen, Midgley, Meites \& Ellis, 1969) and reagents supplied by the NIAMDD. All the serum samples were assessed in a single radioimmunoassay to eliminate between-assay variation. Student's $t$ test was used to assess the level of significance.

The normal release of prolactin induced by suckling was prevented by L-DOPA during the first $90 \mathrm{~min}$ after suckling (Text-fig. 1). A peak in serum prolactin concentration was obtained at $120 \mathrm{~min}$ $(P<0.001)$. At 150 min serum prolactin was still significantly higher than the pre-suckling values of control rats $(P<0.005)$, but a progressive decrease occurred at 180 and $210 \mathrm{~min}$ after the suckling period. The mean values at 180 and 210 min were not significantly different from the control presuckling level and the levels obtained in the first 90 min after suckling in the treated rats.

In order to see if the peak serum prolactin level obtained 120 and $150 \mathrm{~min}$ after the suckling period in rats treated with L-DOPA was due to the suckling stimulus and was not a secondary effect of L-DOPA at the central nervous system, rats in Group 2 were similarly treated with L-DOPA but the suckling stimulus was omitted. The serum prolactin concentration was estimated at 90,180 , 210 and $270 \mathrm{~min}$ after the L-DOPA injection, corresponding to the 30,120,150 and 210 min times for the Group 1 rats. At none of the times studied was the serum prolactin level significantly different from the mean value in control rats before suckling and no peaks were observed.

Four rats in Group 3 were treated with L-DOPA and the effect of the suckling stimulus at the central nervous system was prevented by i.p. injection of sodium pentobarbitone (Nembutal: Abbott; $2 \mathrm{mg} / 100 \mathrm{~g}$ body wt) $30 \mathrm{~min}$ before the suckling period. The mean ( \pm S.E.M.) serum prolactin level $120 \mathrm{~min}$ after suckling $(17 \cdot 8 \pm 5.6 \mathrm{ng} / \mathrm{ml})$ was significantly less than the values obtained in Group $1(593.5 \pm 112.6 \mathrm{ng} / \mathrm{ml} ; P<0.001)$ and Group $2(47.8 \pm 2 \cdot 1 \mathrm{ng} / \mathrm{ml} ; P<0 \cdot 01)$ rats.

As shown in Text-fig. 1, the inhibitory effect of L-DOPA on the secretion of prolactin after suckling lasted for about $90 \mathrm{~min}$ and thereafter a significant increase in serum prolactin concentration occurred. That the peak of serum prolactin was not due to a secondary effect of L-DOPA at the hypothalamic or pituitary level is shown by the results when the suckling stimulus was absent or its 


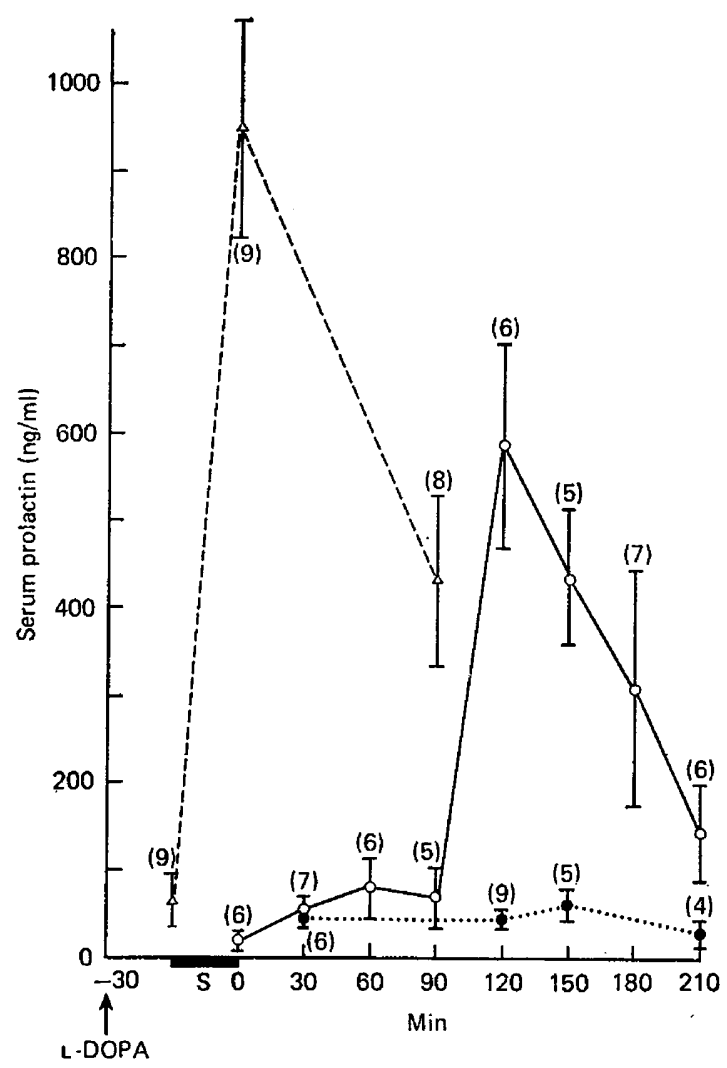

Text-fig. 1. Mean ( $($ S.E.M.) serum prolactin concentrations in untreated lactating rats $(\Delta)$ before and after a 30-min suckling period (S) and in rats treated with L-DOPA and with (O) or without ( $(\bullet)$ a suckling stimulus. The numbers of rats in each group are shown in parentheses.

effect prevented at the central nervous system. It is evident that the suckling stimulus must be present to induce the delayed increase in serum prolactin concentration. If L-DOPA or dopamine are considered as acting at both the hypothalamic and pituitary level (Ojeda, Harms \& McCann, 1974), it is possible that the monoamines may prevent the release of prolactin from the pituitary but do not affect, at the central nervous system, the action of the suckling stimulus which is still able to induce prolactin release by the time the pituitary is free of the dopamine influence. MacLeod $\&$ Lehmeyer (1974) have demonstrated that prolactin cells in the pituitary gland have dopaminergic or $\alpha$-adrenergic receptors which, when stimulated, inhibit the secretion of prolactin. Preliminary evidence suggests that $\left[{ }^{14} \mathrm{C}\right]$ dopamine is capable of binding to pituitary gland receptor sites. On the other hand the transient nature of the catecholamine effect can be explained by the high monoamine oxidase activity present in the pituitary gland. MacLeod \& Lehmeyer (1972) have shown that a pituitary in which prolactin release was inhibited by catecholamine added to the incubation medium may rapidly recover its capacity to release prolactin when it is transferred to a medium free of monoamines.

The present and previous results (Prilusky \& Deis, 1975) indicate that monoamines, probably dopamine, may have an important function in controlling prolactin release in lactating rats.

We thank Mr E. Molina for the care of the animals and technical assistance. The work was supported by a grant from the Consejo Nacional de Investigaciones Científicas y Técnicas of Argentina, of which R.P.D. is a career scientist and J.P. a post-doctoral fellow. We are grateful to Labora- 
torios Massone, Argentina, for the gift of L-DOPA. The NIAMDD rat pituitary hormone distribution program kindly supplied the radioimmunoassay kit for prolactin.

\section{References}

Donoso, A.O., Bishop, W., FAWCETt, C.P., KRULich, L. \& MCCANN, S.M. (1971) Effects of drugs that modify brain monoamine concentration on plasma gonadotropin and prolactin levels in the rat. Endocrinology 89, 774-784.

MACLEOD, R.M. (1969) Influence of norepinephrine and catecholamine-depleting agents on the synthesis and release of prolactin and growth hormone. Endocrinology 85, 916-923.

MACLEOD, R.M. \& LeHMEYER, J.E. (1972) Regulation of the synthesis and release of prolactin. In Lactogenic Hormones, Ciba Foundation Symposium, pp. 53-76. Eds G. E. W. Wolstenholme \& J. Knight. Churchill Livingstone, London.

MACLEOD, R.M. \& LeHMEYER, J.E. (1974) Studies on the mechanism of the dopamine-mediated inhibition of prolactin secretion. Endocrinology 94, 1077-1085.

NisWender, G.D., Chen, C.I., Midgley, A.R., JR, Meites, J. \& Eluis, S. (1969) Radioimmunoassay for rat prolactin. Proc. Soc. exp. Biol. Med. 130, 793-797.

Ojeda, S.R., Harms, P.G. \& McCaNN, S.M. (1974) Effect of blockage of dopamine receptors on prolactin and $\mathrm{LH}$ release: median eminence and pituitary site of action. Endocrinology 94, 1650-1657.

Prilusky, J. \& DeIs, R.P. (1975) Effect of L-DOPA on milk ejection and on prolactin release in lactating rats. J. Endocr. (in press).

Vermouth, N.T. \& DeIs, R.P. (1974) Prolactin release and lactogenesis after ovariectomy in pregnant rats: effect of ovarian hormones. J. Endocr. 63, 13-20.

Received 4 July 1975 